\title{
A Discipline-Spanning Overview of Action Research and Its Implications for Technology and Innovation Management
}

\author{
Matthias Guertler, Nathalie Sick, and Anton Kriz
}

\author{
(6 If you want truly to understand something, try to change it. ") \\ Kurt Lewin \\ Psychologist, considered the founder of social psychology
}

\begin{abstract}
The iterative and learning character of action research is particularly beneficial for exploring complex socio-technical problems in technology and innovation management (TIM). In this respect, action research allows both rigorous and relevant research due to parallel solving of real-world problems, capability building, and gaining scientific insights. However, the use of action research within TIM research is surprisingly limited. Action research also is not a homogeneous research methodology since each research discipline, such as education and organizational science, has its own action research streams, which are often only loosely linked. A systematic overview of those action research traditions and specific best practices is still missing, which complicates a systematic transfer and use of action research in TIM. This article addresses this essential gap by building a cross-disciplinary overview of action research streams based on a bibliometric analysis using Scopus. The analysis includes relevant disciplines with action research traditions, their development over time, and the most influential journals, authors, institutions, and countries. Along with this discipline-spanning analysis, the article investigates particular TIM benefits and challenges of action research. The two key contributions of this article are: 1) a discipline-spanning overview of action research and its evolution and 2) an analysis of its implications for TIM research. These contributions build the basis for strengthening the use of action research in TIM. In the medium-term, action research has the capacity to link academia and industry more closely and, in doing so, assists important endeavours of translating more of our research outcomes into practice.
\end{abstract}

\section{Introduction}

This study provides a discipline-spanning overview of action research and its implications for technology and innovation management (TIM). TIM is characterized by complex socio-technical problems which include the involvement of a large variety of different stakeholders across the entire lifecycle of a product-service system (Kralisch et al., 2018). Moreover, innovation is multi-faceted and can be an outcome, a process, and a capability (D'Alvano \& Hidalgo, 2012; Hauschildt \& Salomo, 2007; Hidalgo \& Albors, 2008). Due to the socio-technical complexity and novelty of innovations, innovation management also faces high levels of uncertainty (D'Alvano \& Hidalgo, 2012).
The iterative learning and human-centred character of action research is particularly beneficial for exploring the complex socio-technical problems in TIM. Understanding the complex systems of technical and social elements, their relationships, and their dynamics can benefit from applied approaches such as action research (Benner \& Tushman, 2015; Ottosson, 2003). In this respect, action research allows both rigorous and relevant research due to parallel resolving of realworld problems, capability building, and gaining scientific insights (Brydon-Miller et al., 2003). However, despite these benefits and successful applications in other disciplines such as education (Hult \& Lennung, 1980), sociology, and experimental psychology (Burnes, 2004), the use of action research within TIM 


\section{A Discipline-Spanning Overview of Action Research and Its Implications for Technology and Innovation Management Matthias Guertler, Nathalie Sick, and Anton Kriz}

research is surprisingly limited. A Scopus search in November 2018, using the terms "action research" and "innovation management" linked to title, abstract, and keywords (before 2018), yielded only 19 journal articles. Action research itself is also not methodologically homogeneous since each research discipline, such as education and organizational science, has their own action research streams, which are often only loosely linked. A systematic overview of those action research streams and specific best practices is still missing, which complicates a systematic transfer and use of action research in TIM.

To allow a successful application of action research in TIM and a systematic transfer of approaches from other disciplines, it is important to build a detailed understanding about the "where" and "why" of action research for TIM as well as "which" and "how" cross-disciplinary approaches can be transferred and adapted. This article contributes to this overarching goal by focusing on the following fundamental questions: Which disciplines have successfully applied action research to date? Which benefits can action research provide to TIM but also which potential barriers might it face?

The present article addresses this essential gap by building a discipline-spanning overview of action research streams based on a bibliometric analysis using Scopus. The analysis includes relevant disciplines with action research traditions, their development over time, and the most influential journals, authors, institutions, and countries. Along with this discipline-spanning analysis, the article investigates and reviews important benefits and challenges of action research for TIM.

The key contributions of this article are twofold. First, the discipline-spanning overview of action research and its evolution provide insights into different disciplinary streams of action research as a basis to deepen and stretch the thinking between TIM and other disciplines applying action research. Second, opportunities and pathways to further discuss and establish the use of action research within the TIM discipline are identified based on the analysis of benefits and challenges for TIM research. In the medium-term, this enables greater academic and industry linkage for more rigorous research and in so doing helps strengthen the translation of research outcomes into practice.

The remainder of this article is structured as follows. The next section provides an overview of the bibliometric analysis including data collection and measures used. Next, findings of the bibliometric analysis are presented, followed by a discussion of the benefits and challenges of action research for technology and innovation management. The study closes with a summary of the main insights and limitations and an outlook on further research.

\section{Research Method}

In order to map the research landscape of action research, a bibliometric analysis of discipline-spanning contributions to the field of action research has been conducted. Bibliometrics as a quantitative statistical analysis originated in library and information science (Broadus, 1987; Pritchard, 1969). The method is now increasingly used in other research areas to map a certain field from a macro-perspective (Zhang et al., 2010).

The bibliometric analysis is based on Scopus, provided by Elsevier B.V., a global database with more than 71 million records, which is a well-established data source for bibliometric analyses (Harzing \& Alakangas, 2016). To cover a broad and particularly discipline-spanning range of contributions, the search term "action research" was used for title, abstract, and keywords. As different disciplines show varying patterns of publishing research results, particularly concerning journal articles, conference proceedings, and books, no limitations were implemented in terms of document types. The search was conducted in November 2018 with results including all material up until the end of 2017. The search resulted in 16,946 documents related to action research. Medicine was excluded as a discipline of analysis due to the high number of false positives, such as "action research arm", "action research aim", and other topics around genetics and stroke therapy. This reduced the sample to 13,727 documents.

In a first step, the disciplines involved in action research were analyzed as well as their respective publication outlets, more specifically peer-reviewed articles and reviews as well as conferences and books or book chapters. In a second step, the sample was reduced to peer-reviewed articles (i.e., articles, articles in press, reviews, editorials, and notes). These articles were analyzed in terms of the most influential journals, authors, contributions, as well as institutions and countries, while providing additional disciplinary insights. Measures used in this study, and established as well as widespread in bibliometrics, are contributions and citations as well as h-index (Hirsch, 2005; Merigó et al., 2015). Using the total number of contributions in combination with citations and h-index captures the extent as well as 


\section{A Discipline-Spanning Overview of Action Research and Its Implications for Technology and Innovation Management Matthias Guertler, Nathalie Sick, and Anton Kriz}

the outreach and influence of contributions in the field (Ding et al., 2014).

In addition to the quantitative bibliometric analysis, qualitative insights are added to complete the discipline-spanning review of action research with a discussion of benefits and challenges particularly to TIM.

\section{Discipline-Spanning Bibliometric Overview of Action Research Literature}

\section{General overview}

As of November 2018, 13,727 documents on action research have been published. Peer-reviewed articles hold the biggest share with $79 \%$, followed by conference papers with $14 \%$ and books, as well as book chapters with $7 \%$. Table 1 provides an overview of the most relevant disciplines with more than 500 publications on action research. A disciplinary analysis reveals that social science is the dominant discipline,

Table 1. Overview of central disciplines in action research

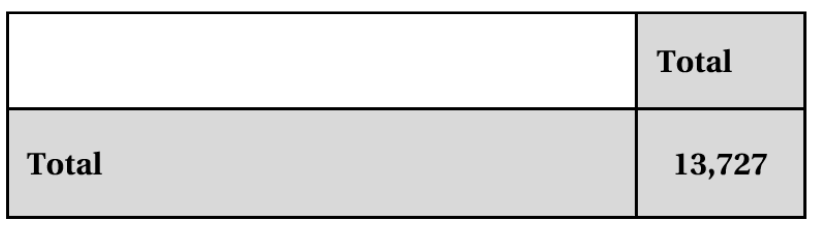

\begin{tabular}{|l|c|}
\hline Social Science & 7,924 \\
\hline Business, Management, and Accounting & 2,829 \\
\hline Computer Science & $20.6 \%$ \\
\hline Engineering & $15.2 \%$ \\
\hline Art and Humanities & 1,288 \\
\hline Psychology & 1,280 \\
\hline Nursing & $9.4 \%$ \\
\hline Decision Science & 1,051 \\
\hline Environmental Science & 897 \\
\hline & $6.7 \%$ \\
\hline & 682 \\
\hline & 673 \\
\hline
\end{tabular}

contributing $58 \%$ of all publications. Business, management, and accounting - including TIM - follows with $21 \%$, while computer science and engineering account for $15 \%$ and $9 \%$, respectively. As publication structure and strategies can vary across disciplines, a detailed analysis of three key outlets of scientific research is given: 1) peer-reviewed articles (i.e., articles, articles in press, reviews, editorials, and notes), 2) conference papers, and 3) books and book chapters. Unsurprisingly, peer-reviewed articles are the key outlet for most disciplines, ranging from $64 \%$ in decision science to $98 \%$ in nursing with an overall average of $79 \%$. Exceptions, as Table 1 highlights, are computer science and engineering, with conference papers the dominant or at least equal outlet for research publication. This might be due to a more prominent role of conferences in these disciplines, which might mean that conference papers need to be considered when analyzing these disciplines, but this requires further research.

\begin{tabular}{|r|r|r|}
\hline $\begin{array}{c}\text { Peer-Reviewed } \\
\text { Articles }\end{array}$ & \multicolumn{1}{c|}{$\begin{array}{c}\text { Conference } \\
\text { Papers }\end{array}$} & $\begin{array}{c}\text { Books \& Book } \\
\text { Chapters }\end{array}$ \\
\hline 10,792 & 1,905 & 953 \\
$78.6 \%$ & $13.9 \%$ & $6.9 \%$ \\
\hline
\end{tabular}

\begin{tabular}{|c|c|c|}
\hline 6,789 & 493 & 624 \\
\hline $85.7 \%$ & $6.2 \%$ & $7.9 \%$ \\
\hline 2,481 & 182 & 152 \\
\hline $87.7 \%$ & $6.4 \%$ & $5.4 \%$ \\
\hline 865 & 1,114 & 71 \\
\hline $41.5 \%$ & $53.4 \%$ & $3.4 \%$ \\
\hline 651 & 548 & 67 \\
\hline $50.5 \%$ & $42.5 \%$ & $5.2 \%$ \\
\hline 1,152 & 15 & 110 \\
\hline $90.0 \%$ & $1.2 \%$ & $8.6 \%$ \\
\hline 924 & 74 & 52 \\
\hline $87.9 \%$ & $7.0 \%$ & $4.9 \%$ \\
\hline 880 & 4 & 12 \\
\hline $98.1 \%$ & $0.4 \%$ & $1.3 \%$ \\
\hline 434 & 230 & 3 \\
\hline $63.6 \%$ & $33.7 \%$ & $0.4 \%$ \\
\hline 599 & 30 & 42 \\
\hline $89.0 \%$ & $4.5 \%$ & $6.2 \%$ \\
\hline
\end{tabular}

timreview.ca 


\section{A Discipline-Spanning Overview of Action Research and Its Implications for Technology and Innovation Management Matthias Guertler, Nathalie Sick, and Anton Kriz}

\section{Evolution of action research in different disciplines}

Analyzing the year-by-year evolution of action research articles published in each discipline reveals a long "incubation phase" between the first publication and an increased publication momentum (Figure 1). The start of a publication stream is considered as two consecutive publications with no more than three gap years. The seminal paper on action research by Kurt Lewin dates back to 1946. This social sciences action research article is seen as the start of all publication streams (Burnes, 2004) and is still seen as seminal in today's action research landscape. In the following five years, the disciplines of business, management, and accounting; arts and humanities; psychology; as well as nursing started publication activities on action research. However, it was not until around the beginning of the 1970s that action research led to a continuous publication stream and began to develop additional intensity. In 1974, decision science published the first action research art- icles with consecutive contributions. Later disciplines are computer science and engineering with smaller gaps of eight and 12 years, with action research only gaining real momentum from the early $80 \mathrm{~s}$. The most recent discipline in our analysis is environmental science starting in 1980.

Figure 1 highlights a marked incline in publications in social sciences from the 1980s with this catapulting after 2004. A more general incline across respective disciplines is observed with the turn of the millennium. The growth factor of the annual publication rates from 2000 until 2017 ranges from 1.0 for nursing and 2.5 for psychology up to 32.0 for engineering. Decision science and business, management, and accounting represent the lower middle field with a growth factor of 3.5 and 4.2 respectively. The upper middle field is formed by social science (7.4), computer science (7.7), environmental science (8.8), and arts and humanities (9.6).

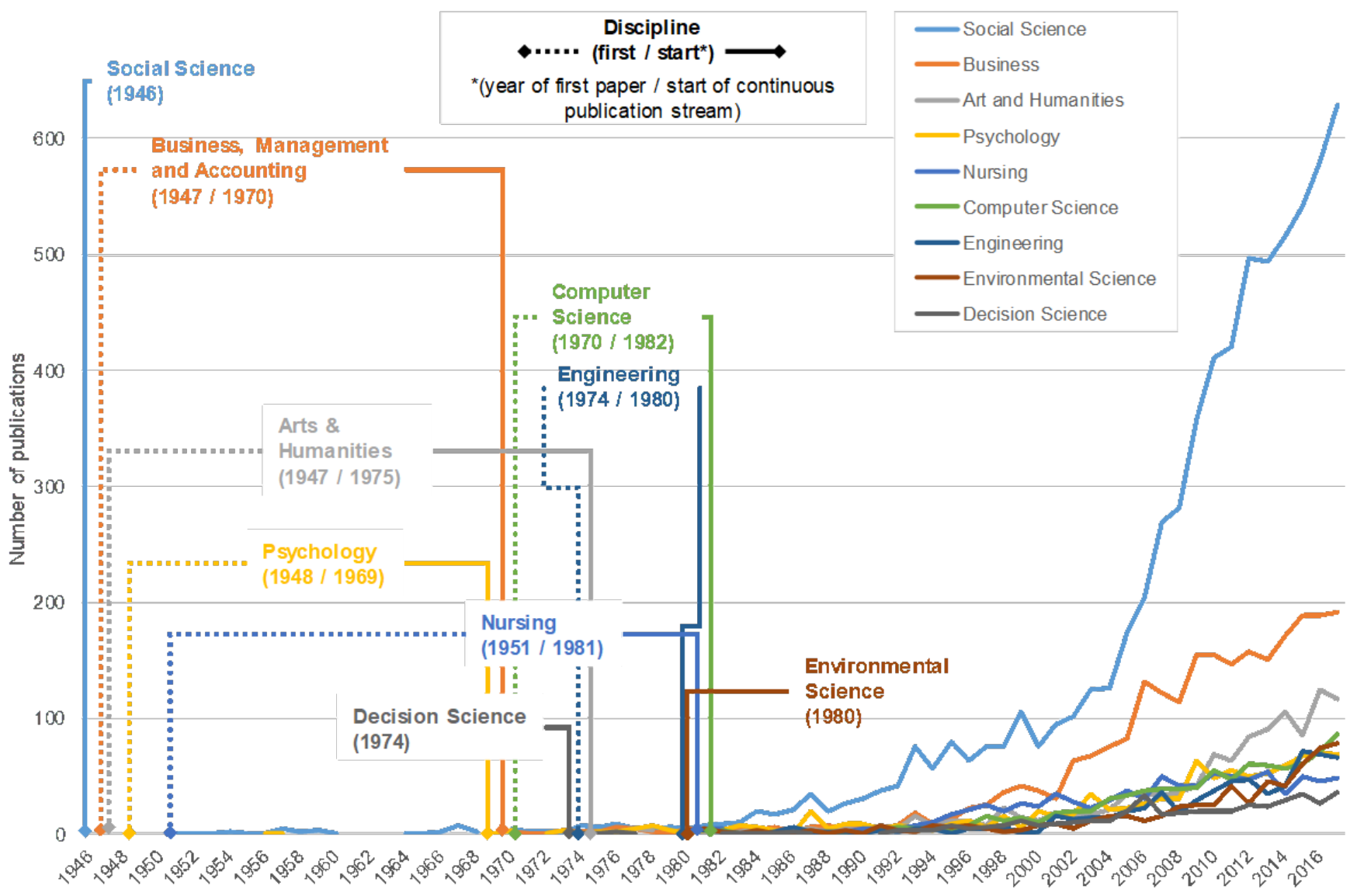

Figure 1. Evolution of new action research publications in the key disciplines 


\section{A Discipline-Spanning Overview of Action Research and Its Implications for Technology and Innovation Management Matthias Guertler, Nathalie Sick, and Anton Kriz}

The most influential journals

Another key aspect of a bibliometric overview of action research is where studies on or involving action research are published, particularly concerning the focus and disciplines. It is striking that the most productive action research journals are specifically dedicated to action research as a research method, for example, Educa- tional Action Research (445 articles), Action Research (298 articles), Systemic Practice and Action Research (221 articles), and the International Journal of Action Research (76 articles) (Table 2). The aforementioned journals are either associated with social science or business, management, and accounting, the two major disciplines in action research (Table 1).

Table 2. Most productive and influential journals publishing action research

\begin{tabular}{|c|c|c|c|c|c|}
\hline & Journal & 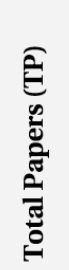 & 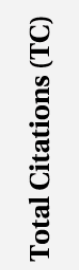 & TC/TP & 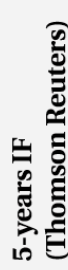 \\
\hline 1 & Educational Action Research & 445 & 3136 & 7.0 & N/A \\
\hline 2 & Action Research & 298 & 3627 & 12.2 & 0.83 \\
\hline 3 & Systemic Practice and Action Research & 221 & 1876 & 8.5 & 0.88 \\
\hline 4 & Journal of Advanced Nursing & 102 & 3137 & 30.8 & 2.76 \\
\hline 5 & Journal of Clinical Nursing & 84 & 1317 & 15.7 & 1.98 \\
\hline 6 & International Journal of Action Research & 76 & 235 & 3.1 & N/A \\
\hline 7 & Teaching and Teacher Education & 52 & 1749 & 33.6 & 3.34 \\
\hline 8 & Nurse Education Today & 47 & 480 & 10.2 & 2.43 \\
\hline 9 & Journal of Applied Behavioral Science & 41 & 954 & 23.3 & 2.18 \\
\hline 10 & Human Relations & 40 & 2486 & 62.2 & 4.35 \\
\hline 11 & Espacios & 36 & 16 & 0.4 & N/A \\
\hline 12 & Learning Organization & 34 & 651 & 19.1 & N/A \\
\hline 13 & AI and Society & 33 & 71 & 2.2 & N/A \\
\hline 14 & British Educational Research Journal & 33 & 718 & 21.8 & 2.29 \\
\hline 15 & Journal of Social Issues & 32 & 2689 & 84.0 & 3.26 \\
\hline 16 & Social Science and Medicine & 32 & 2071 & 64.7 & 3.84 \\
\hline 17 & $\begin{array}{l}\text { International Journal of Operations and } \\
\text { Production Management }\end{array}$ & 31 & 1921 & 62.0 & 4.37 \\
\hline 18 & International Journal of Learning & 30 & 19 & 0.6 & $N / A$ \\
\hline 19 & Management Learning & 30 & 780 & 26.0 & 2.46 \\
\hline 20 & British Journal of Occupational Therapy & 29 & 209 & 7.2 & 0.97 \\
\hline
\end{tabular}

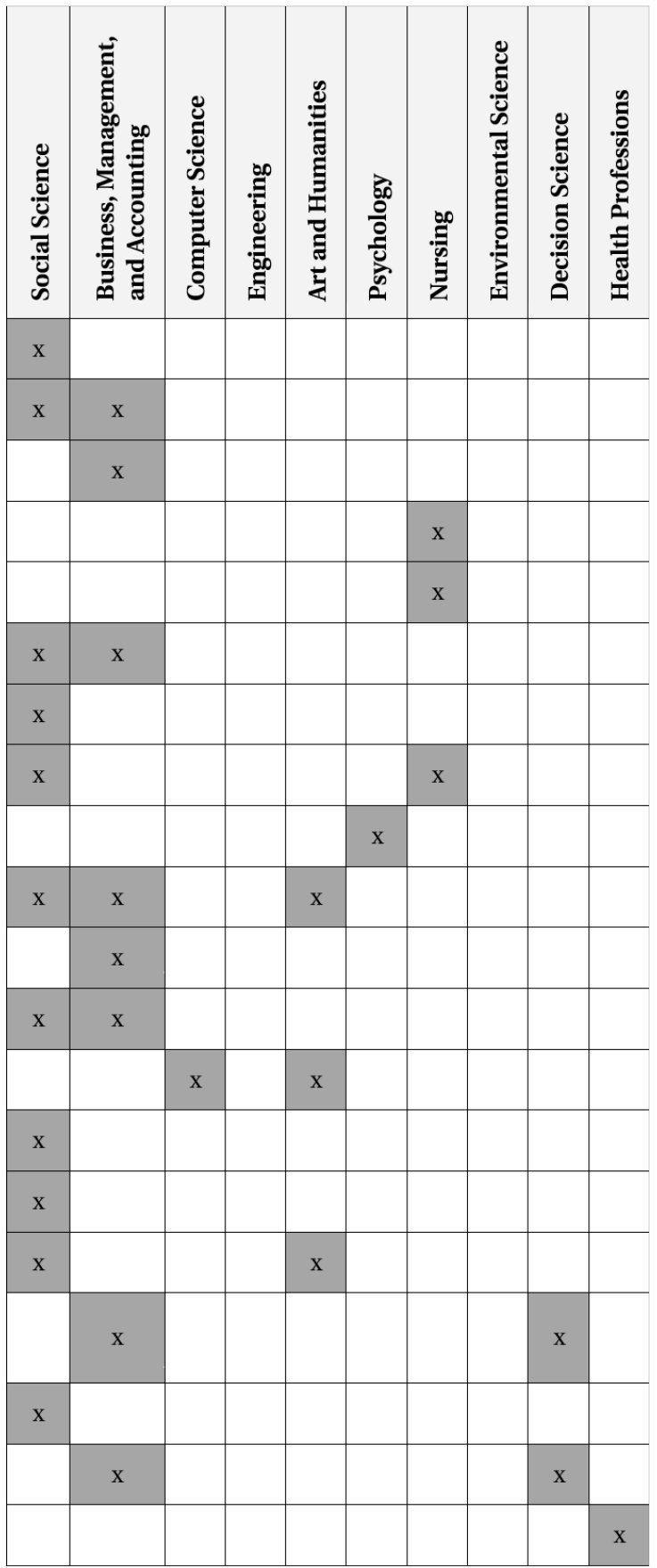




\section{A Discipline-Spanning Overview of Action Research and Its Implications for Technology and Innovation Management Matthias Guertler, Nathalie Sick, and Anton Kriz}

Notably, these more dedicated action research journals are not amongst the most influential journals in terms of citations and impact factor. The highest number of citations per paper (number of total citations "TC" divided by number of total papers "TP") is held by the Journal of Social Issues (84 TC/TP) with the seminal paper by Kurt Lewin from 1946 with 1796 citations, followed by Social Science and Medicine (65 TC/TP), Human Relations (62 TC/TP), and the International Journal of Operations and Production Management (62 TC/TP). Similar to the most productive journals, the most influential ones are attached to social science and business, management, and accounting, but also to arts and humanities and decision science. Underlining the interdisciplinary nature of action research, many journals show affiliations to more than one discipline.

However, no TIM journal can be found amongst the most productive or influential journals. Two findings need to be highlighted in this context: On the one hand, there are very productive dedicated action research journals that focus on action research as a research method. On the other hand, highly influential discipline-specific journals are identified without a particular focus on action research. Despite the inferiority in numbers, it seems that a discussion on the application as well as advantages and challenges of action research is happening on a discipline-specific level. One reason might be that the discussion on when and how to apply action research needs to consider the characteristics and boundary conditions of each discipline, which require and are crucial for discipline-specific action research models.

\section{The most influential articles}

Sorted by average annual citations, Table 3 presents the most influential articles on action research. The work of Israel and co-authors (1998) on community-based research to improve public health is a standout with the highest number of annual citations (125 TC/year). What is striking about the remainder of the articles is the high representation of management and, more specifically, TIM-related topics. In light of the fact that no TIM journal was found amongst the most productive outlets for action research, TIM-related topics and authors seem to be active but are publishing in different domains. "Action Design Research" by Sein and co-authors (2011) is a seminal work published in MIS Quarterly in the management information systems domain. Kaplan's (1999) "Innovation Action Research" is distributed through the Journal of Management Accounting Research in the accounting domain while Linder and Williander's (2017) "Circular Business Model Innovation" is published in
Business Strategy and the Environment in the strategic management domain. More distantly related examples from general management are the study by Kieser and Leiner (2009) on "Why the rigor-relevance in management gap in is unbridgeable" in the Journal of Management Studies or Luescher and Lewis (2008) on "Organizational change and managerial sense making" in the Academy of Management Journal. This dispersion of TIM-related action research articles across non-TIM outlets reinforces the need for a disciplinespanning analysis of action research, in order to build a deep understanding of a successful application and the benefits and challenges of action research for TIM.

\section{The most productive and influential authors (peer-} reviewed)

Nineteen authors with more than ten publications can be found in the action research arena, with David Coghlan the most productive with 44 papers (Table 4). Beyond being productive, he is one of the authors of "Action research for operations management", and in doing so laid the foundation for using action research in operations management (Table 3). Chris Huxham, with a total of 11 contributions, is the most cited and influential author with 112 citations per paper. Reviewing the disciplines associated with the authors' publications in Scopus, it is striking that all authors are linked to social science, the originating and dominant discipline shaping action research. Moreover, most authors have published in a wider variety of disciplines, including medicine; business management, and accounting; arts and humanities; as well as psychology. In contrast, only two authors - John Elliott and Karen Goognough - show a discipline-specific profile with their respective focus on social science and psychology.

\section{The most productive and influential institutions and countries}

The analysis of the most productive and influential institutions and countries reveals that Australia and the UK show strong streams of action research with eight and respectively six institutions in the TOP 20 (Table 5). Major contributions are also available from Brazil, Canada, Denmark, Ireland, and Sweden. Compared to other areas, the country profile seems to be quite specific, with powerful streams of action research in a small number of countries. Interestingly, the research output does not show a high variety between 72 contributions for first ranked Monash University in Australia compared to 51 contributions of Goteborgs Universitet in Sweden on rank 20. While citations per paper are also rather equally distributed, the University of 


\section{A Discipline-Spanning Overview of Action Research and Its Implications for Technology and Innovation Management Matthias Guertler, Nathalie Sick, and Anton Kriz}

Table 3. Overview of most influential articles

\begin{tabular}{|c|c|c|c|c|c|c|}
\hline$\#$ & Authors & Year & Title & Cited By & $\begin{array}{l}\text { Avg. Annual } \\
\text { Citations }\end{array}$ & Journal \\
\hline 1 & $\begin{array}{l}\text { Israel, B.A., Schulz, A.J., } \\
\text { Parker, E.A., Becker, A.B. }\end{array}$ & 1998 & $\begin{array}{l}\text { Review of community-based research: } \\
\text { Assessing partnership approaches to } \\
\text { improve public health }\end{array}$ & 2507 & 125.4 & $\begin{array}{l}\text { Annual Review of Public } \\
\text { Health }\end{array}$ \\
\hline 2 & $\begin{array}{l}\text { Sein, M.K., Henfridsson, } \\
\text { O., Purao, S., Rossi, M., } \\
\text { Lindgren, R. }\end{array}$ & 2011 & Action design research & 555 & 79.3 & $\begin{array}{l}\text { MIS Quarterly: } \\
\text { Management } \\
\text { Information Systems }\end{array}$ \\
\hline 3 & Montero, I., León, O.G. & 2007 & $\begin{array}{l}\text { A guide for naming research studies in } \\
\text { Psychology }\end{array}$ & 582 & 52.9 & $\begin{array}{l}\text { International Journal of } \\
\text { Clinical and Health } \\
\text { Psychology }\end{array}$ \\
\hline 4 & $\begin{array}{l}\text { Linder, M., Williander, } \\
\text { M. }\end{array}$ & 2017 & $\begin{array}{l}\text { Circular business model innovation: } \\
\text { Inherent uncertainties }\end{array}$ & 47 & 47.0 & $\begin{array}{l}\text { Business Strategy and } \\
\text { the Environment }\end{array}$ \\
\hline 5 & $\begin{array}{l}\text { Shirk, J.L., Ballard, H.L., } \\
\text { Wilderman, C.C., } \\
\text { Phillips, T., et al. }\end{array}$ & 2012 & $\begin{array}{l}\text { Public participation in scientific research: A } \\
\text { framework for deliberate design }\end{array}$ & 261 & 43.5 & Ecology and Society \\
\hline 6 & Bock, G.W., Kim, Y.-G. & 2002 & $\begin{array}{l}\text { Breaking the myths of rewards: An } \\
\text { exploratory study of attitudes about } \\
\text { knowledge sharing }\end{array}$ & 681 & 42.6 & $\begin{array}{l}\text { Information Resources } \\
\text { Management Journal } \\
\text { (IRMJ) }\end{array}$ \\
\hline 7 & Catalani, C., Minkler, M. & 2010 & $\begin{array}{l}\text { Photovoice: A review of the literature in } \\
\text { health and public health }\end{array}$ & 310 & 38.8 & $\begin{array}{l}\text { Health Education and } \\
\text { Behavior }\end{array}$ \\
\hline 8 & $\begin{array}{l}\text { Jagosh, J., MacAulay, } \\
\text { A.C., Pluye, P., Salsberg, } \\
\text { J., et al. }\end{array}$ & 2012 & $\begin{array}{l}\text { Uncovering the benefits of participatory } \\
\text { research: Implications of a realist review for } \\
\text { health research and practice }\end{array}$ & 216 & 36.0 & Milbank Quarterly \\
\hline 9 & $\begin{array}{l}\text { Geels, F.W., Berkhout, F., } \\
\text { Van Vuuren, D.P. }\end{array}$ & 2016 & $\begin{array}{l}\text { Bridging analytical approaches for low- } \\
\text { carbon transitions }\end{array}$ & 71 & 35.5 & Nature Climate Change \\
\hline 10 & Cornwall, A., Jewkes, R. & 1995 & What is participatory research? & 809 & 35.2 & $\begin{array}{l}\text { Social Science and } \\
\text { Medicine }\end{array}$ \\
\hline 11 & $\begin{array}{l}\text { Coughlan, P., Coghlan, } \\
\text { D. }\end{array}$ & 2002 & Action research for operations management & 537 & 33.6 & $\begin{array}{l}\text { International Journal of } \\
\text { Operations and } \\
\text { Production } \\
\text { Management }\end{array}$ \\
\hline 12 & *Kaplan, R. S. & 1998 & $\begin{array}{l}\text { Innovation action research: creating new } \\
\text { management theory and practice }\end{array}$ & $668^{*}$ & 33.4 & $\begin{array}{l}\text { Journal of Management } \\
\text { Accounting Research }\end{array}$ \\
\hline 13 & Myers, M.D. & 1997 & Qualitative research in information systems & 688 & 32.8 & $\begin{array}{l}\text { MIS Quarterly: } \\
\text { Management } \\
\text { Information Systems }\end{array}$ \\
\hline 14 & $\begin{array}{l}\text { Lüscher, L.S., Lewis, } \\
\text { M.W. }\end{array}$ & 2008 & $\begin{array}{l}\text { Organizational change and managerial } \\
\text { sensemaking: Working through paradox }\end{array}$ & 326 & 32.6 & $\begin{array}{l}\text { Academy of } \\
\text { Management Journal }\end{array}$ \\
\hline 15 & $\begin{array}{l}\text { Kurtz, C.F., Snowden, } \\
\text { D.J. }\end{array}$ & 2003 & $\begin{array}{l}\text { The new dynamics of strategy: Sense- } \\
\text { making in a complex and complicated } \\
\text { world }\end{array}$ & 489 & 32.6 & IBM Systems Journal \\
\hline 16 & Straub, D.W., Welke, R.J. & 1998 & $\begin{array}{l}\text { Coping with systems risk: Security planning } \\
\text { models for management decision making }\end{array}$ & 614 & 30.7 & $\begin{array}{l}\text { MIS Quarterly: } \\
\text { Management } \\
\text { Information Systems }\end{array}$ \\
\hline
\end{tabular}




\section{A Discipline-Spanning Overview of Action Research and Its Implications for Technology and Innovation Management Matthias Guertler, Nathalie Sick, and Anton Kriz}

Table 3 (continued). Overview of most influential articles

\begin{tabular}{|c|c|c|c|c|c|c|}
\hline \# & Authors & Year & Title & Cited By & $\begin{array}{l}\text { Avg. Annual } \\
\text { Citations }\end{array}$ & Journal \\
\hline 17 & $\begin{array}{l}\text { Avison, D.E., Lau, F., } \\
\text { Myers, M.D., Nielsen, } \\
\text { P.A. }\end{array}$ & 1999 & Action research & 581 & 30.6 & $\begin{array}{l}\text { Communications of the } \\
\text { ACM }\end{array}$ \\
\hline 18 & $\begin{array}{l}\text { Sedlmair, M., Meyer, M., } \\
\text { Munzner, T. }\end{array}$ & 2012 & $\begin{array}{l}\text { Design study methodology: Reflections } \\
\text { from the trenches and the stacks }\end{array}$ & 177 & 29.5 & $\begin{array}{l}\text { IEEE Transactions on } \\
\text { Visualization and } \\
\text { Computer Graphics }\end{array}$ \\
\hline 19 & $\begin{array}{l}\text { Chatti, M.A., Dyckhoff, } \\
\text { A.L., Schroeder, U., Thüs, } \\
\text { H. }\end{array}$ & 2012 & A reference model for learning analytics & 173 & 28.8 & $\begin{array}{l}\text { International Journal of } \\
\text { Technology Enhanced } \\
\text { Learning }\end{array}$ \\
\hline 20 & $\begin{array}{l}\text { Puhakainen, P., Siponen, } \\
\text { M. }\end{array}$ & 2010 & $\begin{array}{l}\text { Improving employees' compliance through } \\
\text { information systems security training: An } \\
\text { action research study }\end{array}$ & 216 & 27.0 & $\begin{array}{l}\text { MIS Quarterly: } \\
\text { Management } \\
\text { Information Systems }\end{array}$ \\
\hline 21 & $\begin{array}{l}\text { Jacobs, S., Dendoncker, } \\
\text { N., Martín-López, B., } \\
\text { Barton, D.N., Gomez- } \\
\text { Baggethun, E., et al. }\end{array}$ & 2016 & $\begin{array}{l}\text { A new valuation school: Integrating diverse } \\
\text { values of nature in resource and land use } \\
\text { decisions }\end{array}$ & 52 & 26.0 & Ecosystem Services \\
\hline 22 & Sebanz, N., Knoblich, G. & 2009 & $\begin{array}{l}\text { Prediction in joint action: What, when, and } \\
\text { where }\end{array}$ & 231 & 25.7 & $\begin{array}{l}\text { Topics in Cognitive } \\
\text { Science }\end{array}$ \\
\hline 23 & $\begin{array}{l}\text { Baum, F., MacDougall, } \\
\text { C., Smith, D. }\end{array}$ & 2006 & Participatory action research & 303 & 25.3 & $\begin{array}{l}\text { Journal of Epidemiology } \\
\text { and Community Health }\end{array}$ \\
\hline 24 & $\begin{array}{l}\text { Shannon, K., Kerr, T., } \\
\text { Allinott, S., Chettiar, J., } \\
\text { Shoveller, J., Tyndall, } \\
\text { M.W. }\end{array}$ & 2008 & $\begin{array}{l}\text { Social and structural violence and power } \\
\text { relations in mitigating HIV risk of drug- } \\
\text { using women in survival sex work }\end{array}$ & 252 & 25.2 & $\begin{array}{l}\text { Social Science and } \\
\text { Medicine }\end{array}$ \\
\hline 25 & $\begin{array}{l}\text { Baskerville, R.L., Wood- } \\
\text { Harper, A.T. }\end{array}$ & 1996 & $\begin{array}{l}\text { A critical perspective on action research as a } \\
\text { method for information systems research }\end{array}$ & 550 & 25.0 & $\begin{array}{l}\text { Journal of Information } \\
\text { Technology }\end{array}$ \\
\hline 26 & Lewin, K. & 1946 & Action research and minority problems & 1792 & 24.9 & Journal of Social Issues \\
\hline 27 & Wang, C.C. & 1999 & $\begin{array}{l}\text { Photovoice: A participatory action research } \\
\text { strategy applied to women's health }\end{array}$ & 469 & 24.7 & $\begin{array}{l}\text { Journal of Women's } \\
\text { Health }\end{array}$ \\
\hline 28 & Case, J.M., Light, G. & 2011 & $\begin{array}{l}\text { Emerging methodologies in engineering } \\
\text { education research }\end{array}$ & 172 & 24.6 & $\begin{array}{l}\text { Journal of Engineering } \\
\text { Education }\end{array}$ \\
\hline 29 & $\begin{array}{l}\text { Davison, R.M., } \\
\text { Martinsons, M.G., Kock, } \\
\text { N. }\end{array}$ & 2004 & Principles of canonical action research & 344 & 24.6 & $\begin{array}{l}\text { Information Systems } \\
\text { Journal }\end{array}$ \\
\hline 30 & $\begin{array}{l}\text { Kohler, T., Fueller, J., } \\
\text { Matzler, K., Stieger, D. }\end{array}$ & 2011 & $\begin{array}{l}\text { Co-creation in virtual worlds: The design of } \\
\text { the user experience }\end{array}$ & 165 & 23.6 & $\begin{array}{l}\text { MIS Quarterly: } \\
\text { Management } \\
\text { Information Systems }\end{array}$ \\
\hline 31 & Kieser, A., Leiner, L. & 2009 & $\begin{array}{l}\text { Why the rigour-relevance gap in } \\
\text { management research is unbridgeable }\end{array}$ & 212 & 23.6 & $\begin{array}{l}\text { Journal of Management } \\
\text { Studies }\end{array}$ \\
\hline
\end{tabular}




\section{A Discipline-Spanning Overview of Action Research and Its Implications for Technology and Innovation Management Matthias Guertler, Nathalie Sick, and Anton Kriz}

Table 4. The most productive and influential authors

\begin{tabular}{|c|c|c|c|c|c|c|}
\hline & Author & 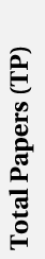 & 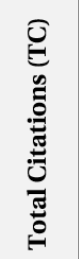 & TC/TP & $\mathbf{h}$ & Organization \\
\hline 1 & Coghlan, David & 44 & 1462 & 33.2 & 19 & $\begin{array}{l}\text { Trinity College Dublin, } \\
\text { Ireland }\end{array}$ \\
\hline 2 & Flood, Robert Louis & 23 & 157 & 6.8 & 15 & $\begin{array}{l}\text { Norges Teknisk- } \\
\text { Naturvitenskapelige } \\
\text { Universitet, Norway }\end{array}$ \\
\hline 3 & Kock, Ned Florencio & 20 & 831 & 41.6 & 30 & $\begin{array}{l}\text { Texas A and M International } \\
\text { University, USA }\end{array}$ \\
\hline 4 & Eilks, Ingo & 17 & 326 & 19.2 & 17 & $\begin{array}{l}\text { University of Bremen, } \\
\text { Germany }\end{array}$ \\
\hline 5 & Zuber-Skerritt, Ortrun & 17 & 403 & 23.7 & 13 & Griffith University, Australia \\
\hline 6 & Koch, Tina & 16 & 454 & 28.4 & 28 & $\begin{array}{l}\text { University of Newcastle, } \\
\text { Australia }\end{array}$ \\
\hline 7 & Elliott, John & 13 & 316 & 24.3 & 16 & $\begin{array}{l}\text { University of East Anglia, } \\
\text { UK }\end{array}$ \\
\hline 8 & Mathiassen, Lars & 13 & 487 & 37.5 & 29 & $\begin{array}{l}\text { Georgia State University, } \\
\text { USA }\end{array}$ \\
\hline 9 & Robinson, Andrew Lyle & 13 & 150 & 11.5 & 18 & $\begin{array}{l}\text { University of Tasmania, } \\
\text { Australia }\end{array}$ \\
\hline 10 & Dick, Bob & 12 & 241 & 20.1 & 8 & $\begin{array}{l}\text { Southern Cross University, } \\
\text { Australia }\end{array}$ \\
\hline 11 & Lykes, M. Brinton M. & 12 & 213 & 17.8 & 15 & Boston College, USA \\
\hline 12 & Wood, Lesley A. & 13 & 36 & 2.8 & 6 & $\begin{array}{l}\text { North-West University, } \\
\text { South Africa }\end{array}$ \\
\hline 13 & Brydon-Miller, Mary L. & 11 & 458 & 41.6 & 8 & University of Louisville, USA \\
\hline 14 & Fine, Michelle & 11 & 232 & 21.1 & 32 & $\begin{array}{l}\text { The Doctorate-Granting } \\
\text { Institution of the City } \\
\text { University of New York, USA }\end{array}$ \\
\hline 15 & Goodnough, Karen & 11 & 127 & 11.5 & 8 & $\begin{array}{l}\text { Memorial University of } \\
\text { Newfoundland, Canada }\end{array}$ \\
\hline 16 & Haslett, Tim & 11 & 94 & 8.5 & 8 & $\begin{array}{l}\text { University of Technology } \\
\text { Sydney, Australia }\end{array}$ \\
\hline 17 & Huxham, Chris & 11 & 1227 & 111.5 & 23 & $\begin{array}{l}\text { University of Strathclyde, } \\
\text { UK }\end{array}$ \\
\hline 18 & Reason, Peter & 11 & 458 & 41.6 & 14 & University of Bath, UK \\
\hline 19 & Spirig, Rebecca & 11 & 47 & 4.3 & 14 & $\begin{array}{l}\text { UniversitatsSpital Zurich, } \\
\text { Switzerland }\end{array}$ \\
\hline
\end{tabular}

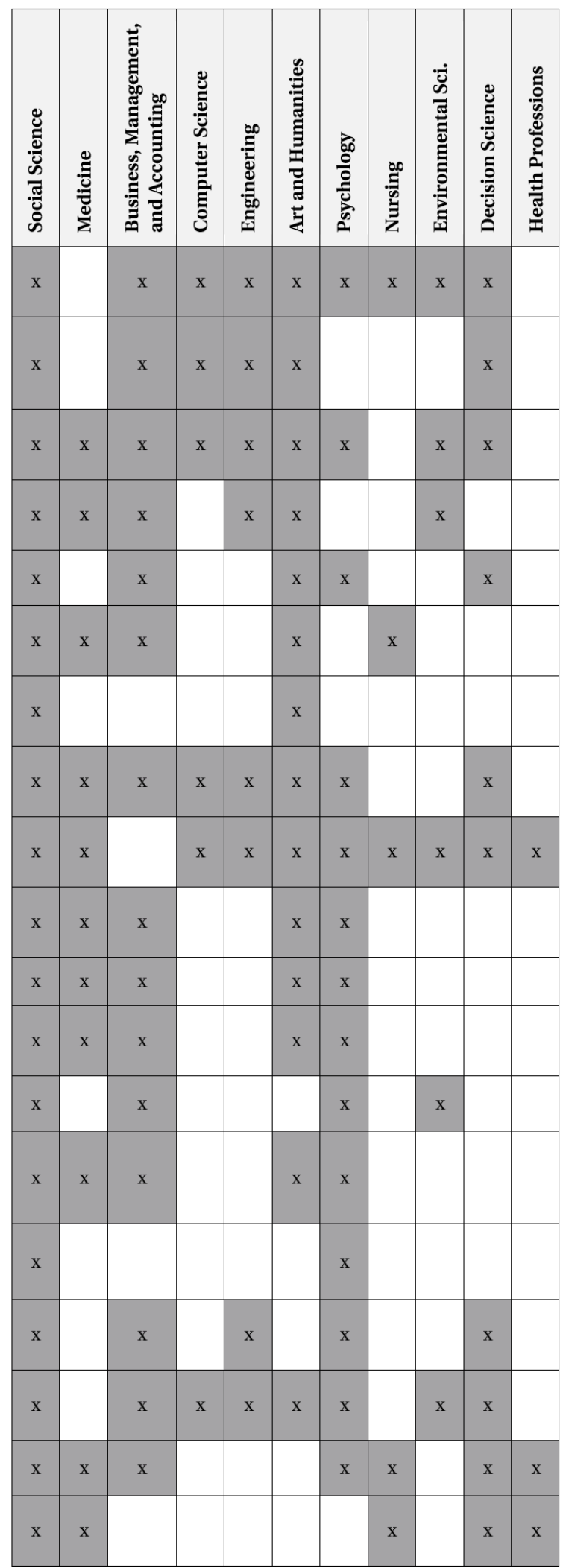




\section{A Discipline-Spanning Overview of Action Research and Its Implications for Technology and Innovation Management Matthias Guertler, Nathalie Sick, and Anton Kriz}

Table 5. Overview of institutions and countries

\begin{tabular}{|c|c|c|c|c|c|}
\hline & University / Institution & $\mathbf{T P}$ & TC & TC/TP & Country \\
\hline 1 & Monash University & 72 & 1449 & 20.1 & Australia \\
\hline 2 & The University of British Columbia & 71 & 1542 & 21.7 & Canada \\
\hline 3 & Queensland University of Technology & 71 & 830 & 11.7 & Australia \\
\hline 4 & Griffith University & 67 & 990 & 14.8 & Australia \\
\hline 5 & University of Manchester & 65 & 1651 & 25.4 & UK \\
\hline 6 & University of Queensland & 63 & 868 & 13.8 & Australia \\
\hline 7 & University of South Australia & 60 & 580 & 9.7 & Australia \\
\hline 8 & Universidade de Sao Paulo & 58 & 281 & 4.8 & Brazil \\
\hline 9 & University of Sheffield & 57 & 990 & 17.4 & UK \\
\hline 10 & University of Toronto & 57 & 1225 & 21.5 & Canada \\
\hline 11 & University of Technology Sydney & 56 & 512 & 9.1 & Australia \\
\hline 12 & Aalborg Universitet & 54 & 811 & 15.0 & Denmark \\
\hline 13 & University of Melbourne & 54 & 797 & 14.8 & Australia \\
\hline 14 & Curtin University & 54 & 291 & 5.4 & Australia \\
\hline 15 & Trinity College Dublin & 53 & 1531 & 28.9 & Ireland \\
\hline 16 & University of Leeds & 53 & 996 & 18.8 & UK \\
\hline 17 & University of Salford & 52 & 2164 & 41.6 & UK \\
\hline 18 & Loughborough University & 51 & 917 & 18.0 & UK \\
\hline 19 & Open University & 51 & 781 & 15.3 & UK \\
\hline 20 & Goteborgs Universitet & 51 & 1028 & 20.2 & Sweden \\
\hline
\end{tabular}

\begin{tabular}{|c|c|c|}
\hline & Country & TP \\
\hline 1 & USA & 2339 \\
\hline 2 & UK & 2203 \\
\hline 3 & Australia & 1168 \\
\hline 4 & Canada & 656 \\
\hline 5 & Brazil & 340 \\
\hline 6 & Sweden & 306 \\
\hline 7 & Spain & 291 \\
\hline 8 & South Africa & 282 \\
\hline 9 & Netherlands & 267 \\
\hline 10 & New Zealand & 244 \\
\hline 11 & Finland & 227 \\
\hline 12 & Italy & 205 \\
\hline 13 & Norway & 194 \\
\hline 14 & Germany & 191 \\
\hline 15 & Ireland & 179 \\
\hline 16 & France & 172 \\
\hline 17 & Denmark & 165 \\
\hline 18 & Thailand & 125 \\
\hline 19 & Taiwan & 124 \\
\hline 20 & China & 118 \\
\hline
\end{tabular}




\section{A Discipline-Spanning Overview of Action Research and Its Implications for Technology and Innovation Management Matthias Guertler, Nathalie Sick, and Anton Kriz}

Salford in the UK is the most influential institution with 42 citations per paper followed by Trinity College Dublin, Ireland, with 29. Although the USA show the highest number of articles per country (2339 articles), no US university/institution is amongst the TOP 20 universities. From a country perspective, the TOP 3 countries show a big lead to all following countries of the TOP 20.

\section{The most productive and influential institutions and countries}

Figure 2 presents the key institutions in the highlighted most active countries along with their most dominant disciplines. Social science and business, management, and accounting are well represented in the most active countries. Nursing, as well as arts and humanities, follow in the UK, Australia, and Canada, with the UK focusing on computer science in contrast to psychology in Australia and Canada. Action research in the US is positioned stronger in psychology, arts and humanities, and computer science. Brazil, in contrast, shows a slightly different profile. While social sciences and busi- ness, management, and accounting are less dominant, action research is also robust in engineering and decision science.

\section{Synthesis of findings}

The bibliometric analysis revealed that action research is applied in a variety of disciplines, with social science clearly the strongest and business, management, and accounting (including TIM) following in second. The first and seminal publication by Lewin (1946) started the action research journey with publication activity often exhibiting long incubation phases. Publications on action research gained real momentum after the turn of the millennium with the steepest increases in engineering. In addition to disciplinary streams, action research also shows particular strength in specific countries such as the USA, the UK, and Australia - although it might be interesting to investigate the influence of different cultural publication traditions onto these numbers. It is striking that the most productive journals (total number of articles) publishing action research are

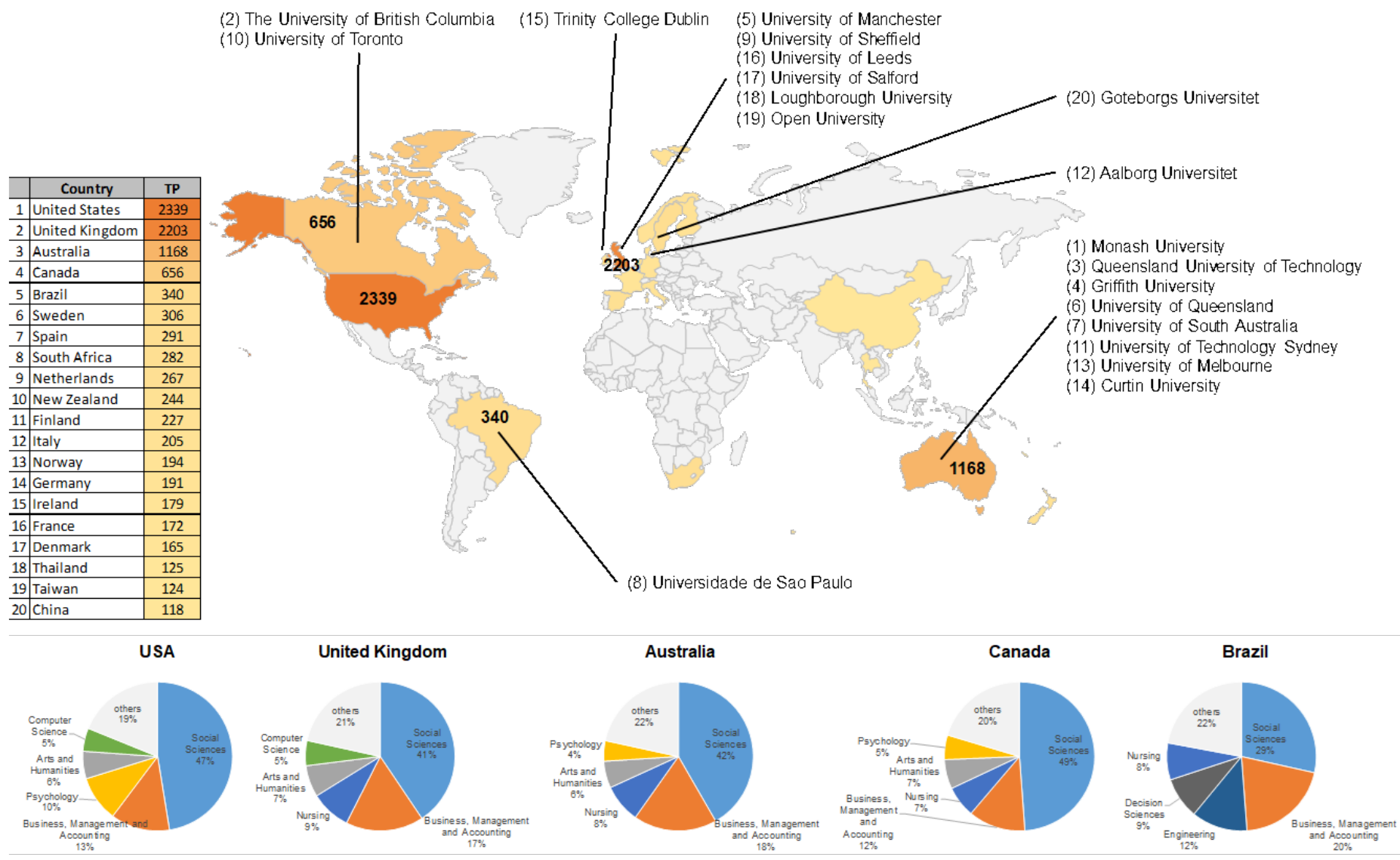

Figure 2. Global overview of most productive and influential institutions and authors 


\section{A Discipline-Spanning Overview of Action Research and Its Implications for Technology and Innovation Management Matthias Guertler, Nathalie Sick, and Anton Kriz}

discipline-spanning and action research specific, while the most influential journals as well as articles (impact factor, citations per article) are published in disciplinespecific journals. Although TIM journals are not represented among the most productive or influential journals, TIM-related topics hold a fair share of the most influential articles in the action research domain. Most of these articles were published in journals from other disciplines, which aligns with the small number of 19 dedicated action research articles in TIM or innovation management in general. This might indicate that researchers interested in publishing action research articles aim for journals in disciplines, where action research is more accepted. This stresses the need for a discipline-spanning analysis to understand the benefits and challenges of action research in TIM for a successful application. A subsequent qualitative analysis of action research literature reveals the benefits and challenges of action research for TIM.

\section{Action Research Benefits and Challenges for Technology and Innovation Management}

Following on from the bibliometric analysis, it became clear that action research approaches are scattered throughout a wide variety of disciplines, from which a TIM-specific model is yet to emerge. The specific developments of action research streams in different disciplines also highlighted the need for tailored approaches to account for the varying boundary conditions and requirements in each discipline. The following qualitative literature analysis aims to take an initial step towards a TIM-specific action research approach by discussing the benefits and challenges of action research highlighted in the different disciplinary streams from a TIM perspective (Table 6). For this purpose, the central elements of TIM mentioned in the introduction are related to the respective benefits and challenges of action research:

- Socio-technical character of innovation problems and systems

- Multi-faceted character of innovations and innovators

- Variety of innovation management stakeholders

- High levels of uncertainty around innovations

This discussion can serve as a foundation for developing a TIM-tailored action research approach based on insights and learnings from a variety of other disciplines.

\section{Benefits of action research}

Action research has an interdisciplinary character, which helps to overcome established discipline structures and "silos". This is necessary to deeply understand socio-technical innovation systems and different dimensions of innovators (Levin, 2012), which are characteristic of TIM. In this respect, the non-linear but iterative action research process spiraling around inherent learning and knowledge development (Herr \& Anderson, 2005; Lewin, 1946) helps to explore TIM problems with a high level of technological and human uncertainty and ambiguity.

Action research allows for the advancement of theory while solving real-world problems, as does TIM (Hult \& Lennung, 1980; Levin, 2012; Mumford, 2001; Ottosson, 2003). A central advantage is the capability of combining rigour and relevance as complementary rather than antitheses (Flyvbjerg \& Sampson, 2011; Levin, 2012; Mumford, 2001) with validity, depth, and a holistic research understanding identified as not necessarily compromising rigour (Eikeland, 2006). This overcomes the risk of basic or applied research being isolated and irrelevant (Flyvbjerg \& Sampson, 2011; Levin, 2012; Ottosson, 2003) including direct evaluation of research results and theories as well as in-depth insights around TIM-related company processes and structures (Susman \& Evered, 1978).

Like other research techniques, action research requires systematic fact finding, but it has particular strengths in aiding and supporting goal-directed actions for specific organizational contexts (Hult \& Lennung, 1980; Kaplan, 1998; Theodorakopoulos et al., 2012). Socio-technical systems (Levin, 2012), including organizational culture and behaviour as well as broad ranges of interdisciplinary stakeholders (Séror, 1996), demand rigour but also need to be reflective of the changing and ongoing realities. In a complex sociotechnical TIM context with different dimensions of innovators, action research, with its human-centered and client-empowering approach, enables deeper access and utilizes not only explicit but also implicit stakeholder knowledge and feedback on new approaches, interpretation of data, and identified research "anomalies", meaning unexpected findings (Eikeland, 2006; Flyvbjerg \& Sampson, 2011; Hult \& Lennung, 1980; Swann, 2002). These "anomalies" are common in highly uncertain TIM systems. Their systematic investigation sometimes might create better questions and lead to better research. This can reveal underlying cause-effect chains of phenomena and is the basis of improved understanding of TIM theory and models (Susman \& Evered, 1978). 


\section{A Discipline-Spanning Overview of Action Research and Its Implications for Technology and Innovation Management Matthias Guertler, Nathalie Sick, and Anton Kriz}

Lewin (1946) and Arens-Fischer and colleagues (2010) noted the importance of more applied theory when human agency is involved. This potentially generates new theory through practice but also incorporates "active evaluation" of both the "researched" and "researchers" (Brydon-Miller et al., 2003). Closely working with clients also allows for a better understanding of organizational group dynamics and underlying power structures, interests, and interdependencies (cf. Arieli et al., 2009; Flyvbjerg \& Sampson, 2011; Ottosson, 2003). Competence building is a real advantage of action research in TIM since clients are often beneficiaries of training insights - sometimes direct or alternatively through osmosis - while also engaging in the problem-solving process. This has spill-over advantages with potential to increase client commitment. Building trust sets the basis for more sustaining cooperative efforts between academia and clients and inevitably helps transition TIM knowledge and approaches into practice (Kaplan, 1998).

\section{Challenges of action research}

Action research has potential for "shining a light" on real-world and real-time business and industry nuances, yet it still has important challenges. A pertinent issue hampering such a method relates to limited precision in interventions including sub-optimal or non-existent research and research design quality (cf. van Aken, 2004) with increased relevance not sufficient in compensating for poor research design (Eden \& Huxham, 1996; Levin, 2012). Applied TIM research projects often bear the risk of focusing too strongly on a technology development part and neglecting an overarching methodological perspective. Like commensurate methods and designs, action research requires deep expertise and adequate verification and justification of empirical efforts. An inordinate focus around "action", particularly of practitioners consulting in "the field" (e.g. McNiff \& Whitehead, 2003; Starkey et al., 2009), without proper regard to "research" is arguably action research's most contentious challenge.

Another challenge with this form of application-oriented research is a need for researchers to have skilled facilitation, problem solving, and communicative capacity beyond less invasive TIM research methods such as surveys or interviews (cf. Hult \& Lennung, 1980; McGivern \& Fineman, 1983) with such expertise notably not easily acquired (Snoeren et al., 2012). Aligning interests of clients and researchers is a key challenge and is far from trivial. Action researchers exploring sociotechnical TIM problems with high levels of uncertainty also need to be aware and open to unforeseen events and unanticipated findings, which might contradict their prior experience (Hodgkinson \& Rousseau, 2009). This requires appropriate adjustments with trial and error and added time and potential additional resources (Burnes, 2004). Changing course requires researcher resilience due to a lack of a "neat step-by-step approach" (Herr \& Anderson, 2005) and loss of control over variables (McGivern \& Fineman, 1983). Interdependencies within socio-technical innovation systems are a crucial challenge that concomitantly makes prediction and specificity difficult (Burnes, 2004; Lewin, 1947; McGivern \& Fineman, 1983).

Effort, time, and cost of embedding researchers into a socio-technical innovation system with various innovators and stakeholders is a major challenge. Levin (2012) argues that this, along with a usually interdisciplinary character, adds to the complexity of a project. There is also a risk of getting lost in the problem-solving process (Hult \& Lennung, 1980) and getting too close to clients and stakeholders (Snoeren et al., 2012). Awareness of interests, power, and political games becomes critical where researchers are variously involved or embedded in these systems (Mumford, 2001). The variety of innovators and stakeholders requires a careful but challenging selection of willing and suitable project partners and definition of appropriate levels of involvement (Hult \& Lennung, 1980). Fincham and Clark (2009) subsequently argue "research" and "practice" are two distinctive domains with closeness often compromising independence with thorough research techniques actually the responsibility of academics, not practitioners.

Clearly, specialist social exchange competences such as building trust and avoiding controversies require experience and adequate capability (Arieli et al., 2009; Snoeren et al., 2012; Wicks \& Reason, 2009). Nurturing researchers with action research curiosity and capacity with skills in problem solving as well as methodical and social competences is important. It may mean, like anthropologists and ethnographers, TIM researchers need to be willing to "live in the field" (Levin, 2012: 134; McGivern \& Fineman, 1983; Susman \& Evered, 1978). Systematically reflecting on and challenging one's own research and context dependencies to avoid biases are crucial but also fundamental (Levin, 2012; Snoeren et al., 2012; Starkey et al., 2009). Action research also requires the communication of research findings to different communities and TIM stakeholders. Although it is essential, it requires additional effort and experience about how to purposefully present these findings to 


\section{A Discipline-Spanning Overview of Action Research and Its Implications for Technology and Innovation Management Matthias Guertler, Nathalie Sick, and Anton Kriz}

each community (Eikeland, 2006; Hult \& Lennung, 1980; Levin, 2012). In terms of academic publications, action research papers often struggle with word restrictions of journals as a detailed and transparent description of the study and its research design can be quite lengthy. Table 6 summarizes the key arguments above based on a substantive analysis and synthesis of the action research literature in relationship to TIM.

\section{Reflective Conclusion}

The study at hand contributes a quantitative disciplinespanning analysis of different action research streams across the globe as well as a qualitative analysis of benefits and challenges of action research for TIM. First, the close relationship between theory and practice in action research proves to be particularly beneficial to tackle socio-technical innovation problems and therefore bridge the rigour-relevance gap in TIM. However, in comparison to further TIM research methods, additional effort is required to prove the rigour and validity of the method. Second, the interdisciplinary nature of action research aligns well with the multi-faceted character of innovation and helps to span boundaries between disciplinary silos in TIM. On the other hand, TIM researchers need to be prepared and trained in how to take advantage of action research for boundaryspanning purposes. Third, the human-centred and client-empowering action research approach enables the inclusion of the TIM-specific wide variety of stakeholders and the continuous balancing of their interests and requirements. On the flip side, TIM researchers have the responsibility to ensure sufficient closeness between stakeholders and researchers, while maintaining independent research at the same time - which is less of an issue when using other TIM research methods. Fourth, the iterative action research process supports exploration in highly uncertain TIM environments, while the frequent pivots in action research projects are more likely to lead to more disruptive theory extensions. However, there is no TIM-specific action research methodology available that guides TIM researchers through the iterative steps of the action research process. In summary, these insights provide recommendations and avenues for further research on where, when, and how to purposefully use action research in TIM:

- The discipline-spanning bibliometric analysis in this study could be enlarged by using additional measures to identify linkages between TIM and other disciplines, such as co-citations or keyword analyses.
- A detailed qualitative analysis of TIM-specific contributions across journals from different disciplines could add to the current analysis and identify additional strengths and "white spots" of action research in TIM to date.

- Future research should further investigate the potential bidirectional dependencies between a limited acceptance of action research in TIM-related journals and the high number of TIM-related publications in journals from other disciplines. This also includes an analysis of if, where, and how actual action research articles might have been published under a different label. The analysis of the most productive and influential journals can also help researchers to select the most suitable outlet for their publications.

- The research design and study description of action research projects can often be quite lengthy and in conflict with word limitations of journals. The development of a standardized way of describing action research projects could help to save space while ensuring a transparent research description.

- Due to the combination of technological and social aspects of TIM, future studies could explore how action research can be used in interdisciplinary joint projects in combination with other research methodologies. An example might be the development of a product-service system, which brings together technical subject matter experts for developing the system and TIM as well as engineering design researchers exploring the overarching innovation processes.

- Another interesting field of research is how practitioners and their expertise can be utilized best to yield indepth insights and co-create knowledge to advance the TIM body of knowledge. This deep research "in the field" requires further investigations into how rigour and relevance can be combined most efficiently in a TIM environment.

- In the context of the capability building through action research, the link and potential synergies to action learning should be explored in the future. This could benefit teaching and practitioner training of TIM approaches as well as training of action researchers themselves.

- Based on the insights from the abovementioned research endeavours, a TIM-specific action research methodology needs to be developed. Although existing 


\section{A Discipline-Spanning Overview of Action Research and Its Implications for Technology and Innovation Management Matthias Guertler, Nathalie Sick, and Anton Kriz}

Table 6. Technology and innovation management specific benefits and challenges of action research

\begin{tabular}{|c|c|c|}
\hline & Benefits & Challenges \\
\hline $\begin{array}{l}\text { Socio-technical } \\
\text { character of TIM } \\
\text { problems and } \\
\text { contexts }\end{array}$ & $\begin{array}{l}\text { - Continuous alignment of theory and practice } \\
\text { creates holistic understanding of innovation as a } \\
\text { socio-technical system including its } \\
\text { organizational culture and behaviour (Kaplan, } \\
\text { 1998; Ottosson, 2003; Séror, 1996) } \\
\text { - Combination of rigour and relevance allows for } \\
\text { solving real-world TIM problems while } \\
\text { advancing TIM theory (Levin, 2012; Mumford, } \\
\text { 2001) } \\
\text { - Better diffusion of new TIM approaches in } \\
\text { practice to bridge the rigour-relevance gap in } \\
\text { TIM (Kaplan, 1998; Theodorakopoulos et al., } \\
\text { 2012; Yang \& Hsiao, 2009) }\end{array}$ & $\begin{array}{l}\text { - Effort, time, and cost to embed TIM researchers } \\
\text { into a socio-technical innovation system } \\
\text { (Sørensen, Mattsson, \& Sundbo, 2010) } \\
\text { - TIM researchers need to be willing to live “in the } \\
\text { field", which might contradict prior experience } \\
\text { (Levin, 2012; Susman \& Evered, 1978) } \\
\text { - Higher effort compared to further TIM research } \\
\text { methods to ensure and prove validity and rigour } \\
\text { of research (Coughlan \& Coghlan, 2002; Eikeland, } \\
\text { 2006) }\end{array}$ \\
\hline
\end{tabular}

Variety of TIM

stakeholders
- Competence building for clients and researchers (technical and social) for future TIM projects (for details: Arieli et al., 2009; Burnes, 2004; Hult \& Lennung, 1980)

- Human-centred and client-empowering approach enables access to tacit knowledge of TIM stakeholders (Eikeland, 2006; Flyvbjerg \& Sampson, 2011; Hult \& Lennung, 1980)

- Iterative and reflective action research approach allows for continuous balancing of TIM stakeholder needs
- Need to analyze TIM stakeholder networks, interests, and power requires experience and knowledge about individual needs of each community (Mumford, 2001)

- Requires purposeful processing and presentation for each TIM stakeholder community (Eikeland, 2006; Levin, 2012)

- Managing closeness, but also independence of research and practice as a responsibility of TIM researchers (Fincham \& Clark, 2009)
High levels of uncertainty around TIM
- Iterative action research process helps to explore highly uncertain and ambiguous TIM problems (Herr \& Anderson, 2005; Lewin, 1946)

- Alignment of the iterative action research process with the effectuation process in entrepreneurship and TIM (cf. Frederiksen \& Brem, 2017)

- Pivoting in action research projects allows for more disruptive theory improvements in highly uncertain TIM environments
- Iterative action research process and pivoting, including unexpected findings, might contradict TIM researchers' prior experience

- No TIM-specific action research methodology available providing a rigorous step-by-step process (Herr \& Anderson, 2005)

- A detailed description of a study's action research design can be lengthy and conflict with word limitations of journals 


\section{A Discipline-Spanning Overview of Action Research and Its Implications for Technology and Innovation Management Matthias Guertler, Nathalie Sick, and Anton Kriz}

action research methodologies from other disciplines such as "design science research" and "education action research" cannot directly be adopted, they should be carefully analyzed to use their experience and adapt suitable elements.

A better understanding of the application of action research in TIM along with new TIM-specific research methodologies has the potential to enhance academic standing in industry and strengthen the translation of research outcomes into practice. In general, it is crucial to avoid seeing and marketing action research as "the" new research paradigm for TIM. Instead, action research will be a valuable enhancement of the existing TIM research methodology toolbox.

\section{About the Authors}

Matthias Guertler is a Lecturer in Engineering Design at the University of Technology Sydney (UTS), Australia. He holds several degrees in Mechanical Engineering, Engineering Design, and Innovation Management from the Technical University of Munich, Germany. Matthias' transdisciplinary research is at the interface of engineering design and innovation management with a focus on managing open innovation. His action-research-based projects have been in close collaboration with various partners from industry and defense in Germany and Australia.

Nathalie Sick is a Senior Lecturer in Contemporary Technology Management in the Faculty of Engineering and IT at the University of Technology Sydney (UTS), Australia. Prior to joining UTS, she was a Young Research Group Leader with the Helmholtz Institute in Muenster, Germany, as well as a Junior Professor at the University of Muenster. She holds degrees in Management and Engineering as well as a $\mathrm{PhD}$ in Innovation Management. Her research revolves around innovation and technology management with a particular interest in disciplinespanning collaborations and industry convergence.

Anton Kriz is an Associate Professor at the Australian National University (ANU) specializing in the area of strategic innovation management and international marketing. His research focuses on advancing innovation management and innovation champions in enterprises, clusters, and regions through action research and action learning interventions. As part of the Research School of Management at ANU, he also teaches Innovation and New Venture Creation to executives at Tsinghua University in Beijing, China. 


\section{A Discipline-Spanning Overview of Action Research and Its Implications for Technology and Innovation Management Matthias Guertler, Nathalie Sick, and Anton Kriz}

\section{References}

Arens-Fischer, W., Duschek, S., Pfeiffer, S., Renvert, E., Ruping, B., \& Valcárcel, S. 2010. Aktionsforschung - Zeit für eine Neuentdeckung? Action Research - Time for a Rediscovery? In H. Jacobsen (Ed.), Innovationsstrategien jenseits traditionellen Managements. Beiträge zur ersten Tagung des Förderschwerpunkts des BMBF: 130-150. Stuttgart: Fraunhofer-Verlag.

Arieli, D., Friedman, V. J., \& Agbaria, K. 2009. The Paradox of Participation in Action Research. Action Research, 7(3): 263-290. https://doi.org/10.1177/1476750309336718

Benner, M. J., \& Tushman, M. L. 2015. Reflections on the 2013 Decade Award-"Exploitation, Exploration, and Process Management: The Productivity Dilemma Revisited" Ten Years Later. Academy of Management Review, 40(4): 497-514. https://doi.org/10.5465/amr.2015.0042

Broadus, R. N. 1987. Toward a Definition of "Bibliometrics". Scientometrics, 12(5-6): 373-379. https://doi.org/10.1007/BF02016680

Brydon-Miller, M., Greenwood, D., \& Maguire, P. 2003. Why Action Research? Action Research, 1(1): 9-28. https://doi.org/10.1177/14767503030011002

Burnes, B. 2004. Kurt Lewin and the Planned Approach to Change: A Re-appraisal. Journal of Management Studies, 41(6): 977-1002. https://doi.org/10.1111/j.1467-6486.2004.00463.x

Coughlan, P., \& Coghlan, D. 2002. Action Research for Operations Management. International Journal of Operations \& Production Management, 22(2): 220-240. https://doi.org/10.1108/01443570210417515

D’Alvano, L., \& Hidalgo, A. 2012. Innovation management Techniques and Development Degree of Innovation Process in Service Organizations. R\&D Management, 42(1): 60-70. https://doi.org/10.1111/j.1467-9310.2011.00663.x

Ding, Y., Rousseau, R., \& Wolfram, D. (Eds.) 2014. Measuring Scholarly Impact: Methods and Practice. Cham, Switzerland: Springer International Publishing.

Eden, C., \& Huxham, C. 1996. Action Research for Management Research. British Journal of Management, 7(1): 75-86. https://doi.org/10.1111/j.1467-8551.1996.tb00107.x

Eikeland, O. 2006. Validity in Action Research - Validity of Action Research. In K. A. Nielsen \& L. Svensson (Eds.), Action and Interactive Research - Beyond Practice and Theory: 193-240. Maastricht, Netherlands: Shaker.

Fincham, R., \& Clark, T. 2009. Introduction: Can We Bridge the Rigour-Relevance Gap? Journal of Management Studies, 46(3): 510-515.

https://doi.org/10.1111/j.1467-6486.2009.00834.x

Flyvbjerg, B., \& Sampson, S. 2011. Making Social Science Matter: Why Social Inquiry Fails and How It can Succeed Again (13th ed.). Cambridge: Cambridge University Press.

Frederiksen, D. L., \& Brem, A. 2017. How Do Entrepreneurs Think They Create Value?: A Scientific Reflection of Eric Ries? Lean Startup Approach. International Entrepreneurship and Management Journal, 13(1): 169-189. https://doi.org/10.1007/s11365-016-0411-x
Harzing, A.-W., \& Alakangas, S. 2016. Google Scholar, Scopus and the Web of Science: A Longitudinal and Cross-Disciplinary Comparison. Scientometrics, 106(2): 787-804. https://doi.org/10.1007/s11192-015-1798-9

Hauschildt, J., \& Salomo, S. 2007. Innovationsmanagement (4th ed.). Munich: Vahlen.

Herr, K., \& Anderson, G. L. 2005. The Action Research Dissertation: A Guide for Students and Faculty. Thousand Oaks, CA: SAGE Publications.

Hidalgo, A., \& Albors, J. 2008. Innovation Management Techniques and Tools: A Review from Theory and Practice. $R \& D$ Management, 38(2): 113-127. https://doi.org/10.1111/j.1467-9310.2008.00503.x

Hirsch, J. E. 2005. An Index to Quantify an Individual's Scientific Research Output. Proceedings of the National Academy of Sciences of the United States of America, 102(46): 16569-16572. https://doi.org/10.1073/pnas.0507655102

Hodgkinson, G. P., \& Rousseau, D. M. 2009. Bridging the RigourRelevance Gap in Management Research: It's Already Happening! Journal of Management Studies, 46(3): 534-546. https://doi.org/10.1111/j.1467-6486.2009.00832.x

Hult, M., \& Lennung, S.-Å. 1980. Towards a Definition of Action Research: A Note and Bibliography. Journal of Management Studies, 17(2): 241-250. https://doi.org/10.1111/j.1467-6486.1980.tb00087.x

Kaplan, R. S. 1998. Innovation Action Research: Creating New Management Theory and Practice. Journal of Management Accounting Research, 10: 89-118.

Kralisch, D., Ott, D., Lapkin, A. A., Yaseneva, P., Soete, W. de, Jones, M., Minkov, N., \& Finkbeiner, M. 2018. The Need for Innovation Management and Decision Guidance in Sustainable Process Design. Journal of Cleaner Production, 172: 2374-2388. https://doi.org/10.1016/j.jclepro.2017.11.173

Levin, M. 2012. Academic Integrity in Action Research. Action Research, 10(2): 133-149. https://doi.org/10.1177/1476750312445034

Lewin, K. 1946. Action Research and Minority Problems. Journal of Social Issues, 2(4): 34-46. https://doi.org/10.1111/j.1540-4560.1946.tb02295.x

Lewin, K. 1947. Frontiers in Group Dynamics. Human Relations, 1(1): $5-41$. https://doi.org/10.1177/001872674700100103

McGivern, C. K., \& Fineman, S. 1983. Research and Consultancy: Towards a Conceptual Synthesis. Journal of Management Studies, 20(4): 425-439. https://doi.org/10.1111/j.1467-6486.1983.tb00217.x

McNiff, J., \& Whitehead, J. 2003. Action Research: Principles and Practice (2nd ed.). London: Routledge Falmer.

Merigó, J. M., Gil-Lafuente, A. M., \& Yager, R. R. 2015. An Overview of Fuzzy Research with Bibliometric Indicators. Applied Soft Computing, 27: 420-433.

https://doi.org/10.1016/j.asoc.2014.10.035

Mumford, E. 2001. Advice for an Action Researcher. Information Technology \& People, 14(1): 12-27. https://doi.org/10.1108/09593840110384753 


\section{A Discipline-Spanning Overview of Action Research and Its Implications for Technology and Innovation Management Matthias Guertler, Nathalie Sick, and Anton Kriz}

Ottosson, S. 2003. Participation Action Research: A Key to Improved Knowledge of Management. Technovation, 23(2): 87-94. https://doi.org/10.1016/S0166-4972(01)00097-9

Pritchard, A. 1969. Statistical Bibliography or Bibliometrics. Journal of Documentation, 25(4): 348-349.

Séror, A. C. 1996. Action Research for International Information Technology Transfer: A Methodology and a Network Model. Technovation, 16(8): 421-448.

https://doi.org/10.1016/0166-4972(96)00032-6

Snoeren, M. M., Niessen, T. J. H., \& Abma, T. A. 2012. Engagement Enacted: Essentials of Initiating an Action Research Project. Action Research, 10(2): 189-204. https://doi.org/10.1177/1476750311426620

Sørensen, F., Mattsson, J., \& Sundbo, J. 2010. Experimental Methods in Innovation Research. Research Policy, 39(3): 313-322. https://doi.org/10.1016/j.respol.2010.01.006

Starkey, K., Hatchuel, A., \& Tempest, S. 2009. Management Research and the New Logics of Discovery and Engagement. Journal of Management Studies, 46(3): 547-558.

https://doi.org/10.1111/j.1467-6486.2009.00833.x

Susman, G. I., \& Evered, R. D. 1978. An Assessment of the Scientific Merits of Action Research. Administrative Science Quarterly, 23(4): 582.

https://doi.org/10.2307/2392581

Swann, C. 2002. Action Research and the Practice of Design. Design Issues, 18(1): 49-61. https://doi.org/10.1162/07479360252756287

Theodorakopoulos, N., Sánchez Preciado, D. J., \& Bennett, D. 2012. Transferring Technology from University to Rural Industry within a Developing Economy Context: The Case for Nurturing Communities of Practice. Technovation, 32(9-10): 550-559. https://doi.org/10.1016/j.technovation.2012.05.001

van Aken, J. E. 2004. Management Research Based on the Paradigm of the Design Sciences: The Quest for Field-Tested and Grounded Technological Rules. Journal of Management Studies, 41(2): 219-246.

https://doi.org/10.1111/j.1467-6486.2004.00430.x

Wicks, P. G., \& Reason, P. 2009. Initiating Action Research: Challenges and Paradoxes of Opening Communicative Space. Action Research, 7(3): 243-262.

https://doi.org/10.1177/1476750309336715

Yang, H.-L., \& Hsiao, S.-L. 2009. Mechanisms of Developing Innovative IT-Enabled Services: A Case Study of Taiwanese Healthcare Service. Technovation, 29(5): 327-337.

https://doi.org/10.1016/j.technovation.2009.01.006

Zhang, G., Xie, S., \& Ho, Y.-S. 2010. A Bibliometric Analysis of World Volatile Organic Compounds Research Trends. Scientometrics, 83(2): 477-492.

https://doi.org/10.1007/s11192-009-0065-3
Citation: Guertler, M., Sick, N., \& Kriz, A. 2019. A Discipline-Spanning Overview of Action Research and Its Implications for Technology and Innovation Management. Technology Innovation Management Review, 9(4): 48-65.

http://doi.org/10.22215/timreview/1233

Keywords: action research, discipline-spanning analysis, bibliometrics, literature review, technology and innovation management (cc) BY 


\section{TIm Technology Innovation Management Review}

\section{Academic Affiliations and Funding Acknowledgements}
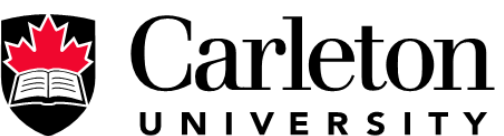

U N I V E R S I T Y

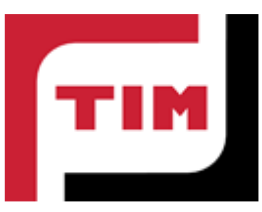

Technology Innovation Management (TIM; timprogram.ca) is an international master's level program at Carleton University in Ottawa, Canada. It leads to a Master of Applied Science (M.A.Sc.) degree, a Master of Engineering (M.Eng.) degree, or a Master of Entrepreneurship (M.Ent.) degree. The objective of this program is to train aspiring entrepreneurs on creating wealth at the early stages of company or opportunity lifecycles.

- The TIM Review is published in association with and receives partial funding from the TIM program. 